\title{
Analisis Normatif Tanggung Jawab Pidana Terhadap Pers Dalam Pemberitaan Yang Mencemarkan Nama Baik
}

\author{
Ruslan Abdul Gani, Muhammad Mustajab \\ Dosen Fakultas Hukum Universitas Batanghari
}

\begin{abstract}
Abstrak. Teknologi komunikasi dan informasi membawa implikasi terhadap dunia penyiaran, termasuk penyiaran di Indonesia. Penyiaran sebagai penyalur informasi dan pembentuk pendapat umum, peranannya semakin sangat strategis, terutama dalam mengembangkan alam demokratis di Indonesia. Penyiaran telah menjadi salah satu sarana berkomunikasi bagi masyarakat lembaga penyiaran, dunia bisnis, dan pemerintah. Perkembangan tersebut telah menyebabkan landasan hukum pengaturan penyiaran yang ada selama ini menjadi tidak memadahi. Dilihat dari arah dan tujuan dari penyelenggaraan penyiaran tersebut, dimana penyiaran sangatlah membantu dalam mencerdaskan meningkatkan sumber daya manusia, namun sangat disayangkan madia massa tersebut sering disalahgunakan oleh orang-orang yang tidak sehingga berakibat merusak nama baik seseorang yang tentunya berimplikasi pada perbuatan melawan hukum yang dapat dikenakan pidana maupun serta denda yang cukup besar. Hasil Temuan diperoleh bahwa Pertanggungjawaban Pers Terhadap yang mencemarkan nama baik seseorang dapat dikenakan sanksi pidana selama 5 (lima) tahun penjara, selain itu pelakunya dapat pula dikenakan Denda paling banyak Rp. 500.000.000,00,- (lima ratus juta rupiah).Tindak pidana yang berhubungan dengan Pers sebelumnya lahirnya Undang-Undang Nomor 40 Tahun 1999 , telah diatur di dalam Kitab Undang-Undang Hukum Pidana seperti, pembocoran rahasia negara melalui surat kabar, Mempertunjukkan atau menempelkan di muka umum yang isinya melanggar kesusilaan lal menyiarkannya untuk dipertontonkan sehingga membangkitkan nafsu birahi dan dan sebagainya.
\end{abstract}

\section{Latar Belakang Masalah}

Kemerdekaan menyatakan pendapat, memperoleh informasi, bersumber dari kedaulatan rakyat dan merupakan hak asasi manusia dalam kehidupan bermasyarakat, berbangsa dan bernegara yang demokratis. Dengan demikian, kemerdekaan atau kebebasan dalam penyiaran harus dijamin oleh negara. Namun sesuai dengan citacita Proklamasi Kemerdekaan Indonesia, maka kemerdekaan tersebut harus bermanfaat bagi upaya bangsa Indonesia dalam menjaga integritas nasional, menegakkan nilai-nilai, dan tata susila, serta memajukan kesejahteraan umum, dan mencerdaskan kehidupan bangsa. Dalam hal ini kebebasan harus dilaksanakan secara bertanggungjawab, selaras dan seimbang antara kebebasan dan kesetaraan menggunakan hak berdasarkan Pancasila dan Undang-Undang Dasar Negara Republik Indonesia Tahun 1945.

Perkembangan teknologi komunikasi dan informasi tersebut telah membawa implikasi terhadap dunia penyiaran, termasuk penyiaran di Indonesia. Penyiaran sebagai penyalur informasi dan pembentuk pendapat umum, peranannya semakin sangat strategis, terutama dalam mengembangkan alam demokratis di Indonesia . Penyiaran telah menjadi salah satu sarana berkomunikasi bagi masyarakat lembaga penyiaran, dunia bisnis, dan pemerintah. Perkembangan tersebut telah menyebabkan landasan hukum pengaturan penyiaran yang ada selama ini menjadi tidak memadahi. Peran serta masyarakat dalam menyelenggarakan sebagian tugas-tugas umum pemerintahan, khususnya di bidang penyelenggaraan penyiaran, tidaklah terlepas dari kaidah-kaidah umum penyelenggaraan telekomunikasi yang berlaku secara universal.

Atas dasar tersebut Pemerintah Republik Indonesia bersama Dewan Perwakilan Rakyat Republik Indonesia menetapkan Undang-Undang Nomor 32 Tahun 2002 Tentang Penyiaran yang telah diundangkan pada tanggal 28 Desember 2002.

Di dalam Undang-Undang nomor 32 Tahun 2002 memuat Azas, Tujuan dan Fungsi dari Penyiaran.

Mengenai Azas dari penyiaran, di dalam Pasal 2 Undang-Undang Nomor 32 Tahun 2002 dijelaskan:

Penyiaran diselenggarakan berdasarkan Pancasila dan Undang-Undang Dasar Negara Republik Indonesia Tahun 1945 dengan azas manfaat, adil, dan merata, kepastian hukum, keamanan, keberagaman, kemitraan, etika, kemandirian, kebebasan, dan tanggungjawab.

Dilihat dari tujuan dari penyiaran diselenggarakan, di dalam Pasal 3 Undang-Undang Nomor 32 Tahun 2002:

Penyiaran diselenggarakan dengan tujuan untuk memperkukuh integritas nasional, terbinanya watak dan jati diri bangsa yang beriman dan bertaqwa, mencerdaskan kehidupan bangsa, memajukan kesejahteraan umum, dalam rangka membangun masyarakat yang mandirim, demokratis, adil dan sejahtera serta menumbuhkan insan penyiaran Indonesia. 
Mengenai fungsi diselenggarakannya lembaga penyiaran, di dalam Pasal 4 Undang-Undang Nomor 32 Tahun 202 dijelaskan:

(1) Penyiaran sebagai kegiatan komunikasi massa mempunhyai fungsi sebagai media informasi, pendidikan, hiburan yang sehat, kontrol dan perekat sosial.

(2) Dalam menjalankan fungsi sebagaimana dimaksud dalam ayat (1), penyiaran juga mempunyai fungsi ekonomis dan kebudayaan.

Berdasarkan ketentuan tersebut di atas, dapatlah dipahami bahwa tujuan dan arah dari penyiaran tersebut adalah untuk menjunjung tinggi pelaksanaan Pancasila dan Undang-Undang dasar Republik Indonesia Tahun 1945. Selain itu penyiaran diarahkan untuk menjaga dan meningkatkan moralitas dan nilai-nilai agama serta jati diri bangsa dan pada akhirnya meningkatkan kualitas sumber daya manusia.

Dilihat dari arah dan tujuan dari penyelenggaraan penyiaran tersebut, dimana penyiaran sangatlah membantu dalam mencerdaskan dan meningkatkan sumber daya manusia, namun sangat disayangkan madia massa tersebut sering disalahgunakan oleh orang-orang yang tidak bertanggungjawab sehingga berakibat merusak nama baik seseorang. ${ }^{1}$

Berkaitan dengan tindak pidana pencemaran nama baik terhadap seseorang yang dilakukan dengan menggunakan media massa atau Pers yang menjadi pertanyaan adalah dapatkah media massa tersebut dimintai pertanggungjawaban secara hukum baik pidana maupun perdata?

Bila dilihat di negara-negara yang menganut sistem hukum civil law maupun common law, umumnya pertanggungjawaban pidana dirumuskan secara negatif. Hal ini berarti dalam hukum pidana Indonesia, sebagai sebagaimana civil law system lainnya, undang-undang justru merumuskan keadaan-keadaan yang dapat menyebabkan pembuat tindak pidana tidak dapat dipertanggungjawabkan. ${ }^{2}$ Dalam praktek peradilan di negaranegara common law, diterima berbagai alasan umum pembelaan ataupun alasan umum peniadaan pertanggungjawaban.

Pertanggungjawaban pidana dipandang ada, kecuali ada alasan penghapusan pidana tersebut. Dengan kata lain, criminal liability dapat dilakukan sepanjang pembuat tidak memiliki defence ketika melakukan suatu tindak pidana. Dalam hukum acara pidana, hal ini berarti seorang terdakwa dipandang bertanggungjawab atas tindak pidana yang dilakukannya, jika tidak dapat membuktikan bahwa dirinya mempunyai "defence" (kesalahan) ketika melakukan tindak pidana. Konsep demikian itu membentuk keseimbangan antara hak mendakwa dan menuntut dari Penuntut Umum, dan hak menyangkal dan mengajukan pembelaan dari terdakwa. $^{3}$

Penuntut Umum berhak untuk mendakwa dan menuntut seseorang karena melakukan tindak pidana. Untuk itu, Penuntut Umum berkewajiban membuktikan apa yang didakwa dan dituntut itu, yaitu membuktikan hal-hal yang termuat dalam rumusan tindak pidana. Sementara itu terdakwa dapat mengajukan pembelaan atas dasar adanya alasan-alasan penghapusan pidana. Untuk menghindar dari pengenaan pidana, terdakwa harus dapat membuktikan bahwa dirinya mempunyai alasan penghapusan pidana kitika melakukan tindak pidana.

Menurut Galligan dalam bukunya Chairul Huda: apabila persyaratan ini diabaikan dan tidak tampak keadaan minimal yang menunjukkan pembuat dapat dicela, maka hukum dan institusi nya telah gagal memenuhi fungsiny. ${ }^{4}$ Dalam mempertanggungjawabkan seseorang dalam hukum pidana, harus terbuka kemungkinan bagi pembuat untuk menjelaskan mengapa dia berbuat demikian. Jika sistem hukum tidak membuka kesempatan demikian, maka dapat dikatakan tidak terjadi proses yang wajar (due process) dalam mempertanggungjawabkan pembuat pidana. Pada gilirannya hal ini akan berhadapan dengan prinsip-prinsip keadilan.

Menurut Chairul Huda: Pertanggungjawaban pidana pertama-tama merupakan keadaan yang ada pada diri pembuat ketika melakukan tindak pidana. Kemudian pertanggungjawaban pidana juga berarti menghubungkan antara keadaan pembuat tersebut dengan pembuat dan sanksi yang sepatutnya dijatuhkan. Dengan demikian, pengkajian dilakukan dua arah. Pertama, pertanggungjawaban pidana ditempatkan dalam kontek sebagai syaratsyarat faktual dari pemidanaan. ${ }^{5}$

\footnotetext{
${ }^{1}$ Sudirman Teba, Hukum Media Massa Nasional, Pustaka Ir Van, Ciputat : 2006. hal. 46.

${ }^{2}$ Andi Zainal Abidin, Hukum Pidana, Jakarta : Sinar Grafika, 2003, hal 62.

${ }^{3}$ Harkristusi Harkrisnowo, Tindak Pidana Kessusilaan Dalam Perspektif Kitab Undang-Undang Hukum Pidana, Jakarta: Pustaka Firdaus, 2001. hal. 91

${ }^{4}$ Chairul Huda, Dari Tiada Pidana Tanpa Kesalahan Menuju Kepada Tiada Pertanggungjawaban Pidana Tanpa Kesalahan, Jakarta: Kencana Prenada Media, 2005, hal. 63.

5 Ibid., hal. 64.
} 
Di Era Reformasi, ditandai dengan mundurnya Presiden Soeharto pada bulan Mei 1999. Dampak dari mundurnya Soeharto membawa perubahan di segala bidang kehidupan termasuk wartawan.

Karena era reformasi ini telah memberi kesempatan pada setiap kelompok masyarakat menampakkan eksistensinya di berbagai bidang kehidupan seperti, politik, hukum, Media Masa atau Pers dan sebagainya. ${ }^{6}$

Pengelompokan masyarakat yang heterogen itu menyeret wartawan/Pers pada berbagai afiliasi dan kepentingan. Hal ini mendorong wartawan untuk berpihak kepada kelompok-kelompok sosial sehingga timbul pertanyaan tentang profil wartawan Indonesia yang ideal.

Wartawan yang ideal bukanlah wartawan yang suka menerima uang. Dimana wartawan tersebut bekerja di media massa tertentu, namun berita yang ditulis atau disiarkan atas permintaan orang atau lembaga yang memberikan uang. Wartawan semacam ini tidak menulis atau menyiarkan informasi yang dia yakini benar, tetapi mengikuti kehendak pemberi uang. Kehendak pemberi uang biasanya ada dua macam, pertama, memberikan uang supaya menyiarkan informasi sesuai dengan kehendaknya. Kedua, memberikan uang kepada wartawan supaya tidak menyiarkan informasi tertentu yang merugikan kepentingan pemberi uang.

Dalam pemberitaan Pers ada juga wartawan yang diberi uang namun berita yang ditayangkan tidaklah untuk merusak nama baik seseorang atau untuk mempengaruhi isi pemberitaan, tetapi sebagai ucapan terima kasih kepada wartawan atas penyiaran beritanya. Mengenai pemberian semacam ini banyak yang membolehkannya, karena tidak mempengaruhi wartawan untuk memberitakan atau tidak suatu kejadian. Sebenarnya yang dilarang adalah wartawan terpengaruh oleh pemberian sumber berita untuk memberitakan atau tidak suatu informasi. Sebab wartawan itu harus netral, mandiri, objektif dan hanya berpihak kepada kebenaran. Kalau wartawan menerima uang untuk menyiarkan atau tidak menyiarkan suatu kejadian, maka sudah pasti tidak netral.

Bila diperhatikan kondisi Pers pada masa Orde Baru masalah SIUPP merupakan masalah yang sangat ditakuti oleh kalangan pers, karena SIUPP suatu perusahaan pers bisa dibatalkan oleh pemerintah. Ini berarti mematikan hak hidup perusahaan pers yang bersangkutan.

Karenanya, ketika era reformasi timbul keinginan untuk membebaskan sama sekali intervensi pemerintah dan menamakan diri sebagai pers yang merdeka atau kemerdekaan pers. Inilah sebabnya kebebasan pers Indonesia dibedakan dengan kemerdekaan pers, walaupun berakar pada konsep atau teori pers yang sama, yaitu pers liberal.

Mengenai pengertian pers itu sendiri, di dalam Pasal 1 butir 1 Undang-Undang Nomor: 40 Tahun 1999 Tentang Pers disebutkan:

Pers adalah lembaga sosial dan wahana komunikasi massa yang melaksanakan kegiatan jurnalistik meliputi mencari, memperoleh, memiliki, menyimpan, mengolah, dan menyampaikan informasi baik dalam bentuk tulisan, suara dan gambar, serta data dan grafik maupun dalam bentuk lainnya dengan menggunakan media cetak, media elektronik, dan segala jenis saluran yang tersedia.

Walaupun pers diberikan kebebasan dalam menyiarkan pemberitaan untuk kepentingan pemerintah, masyarakat maupun komunitas bukan berarti pers seenaknya memuat berita. Akan tetapi pers tetap dapat dituntut secara hukum bila berita/siaran yang dimuat merusak nama baik seseorang.

\section{Perumusan Masalah}

Berdasarkan latar belakang yang telah dikemukakan di atas, maka dapat dirumuskan permasalahan antara lain sebagai berikut:

1. Bagaimana Pertanggungjawaban Pers Terhadap Pemberitaan yang mencemarkan nama baik seseorang ?

2. Tindak Pidana Apa saja yang Berhubungan Dengan Pertanggungjawaban Pers.

\section{Pembahasan}

\section{Pertanggungjawaban Pers Terhadap Pemberitaan yang Mencemarkan Nama Baik Seseorang.}

Mengenai Pertanggungjawaban Pers terhadap pemberitaan yang mencemarkan nama baik seseorang, dimana terhadap Pers yang bersangkutan dapat dikenakan hukuman pidana maupun denda. Di dalam Undang-Undang Republik Indonesia No. 40 Tahun 1999 tentang Pers yang pernah diberlakukan, di dalam Bab VIII Ketentuan Pidana, dimana di dalam Pasal 18 dijelaskan:

(1) Setiap orang yang secara melawan hukum dengan sengaja dan melakukan tindakan yang berakibat menghambat atau menghalangi pelaksanaan ketentuan Pasal 4 ayat (2) dan ayat 3 dipidana dengan pidana penjara paling lama 2 (dua) tahun atau denda paling banyak Rp.500.000.000 (lima ratus juta rupiah).

\footnotetext{
${ }^{6}$ Bambang Poernomo, Azas-azas hukum Pidana, Ghalia Indonesia, Yogyakarta, 2002. hal. 72
} 
(2) Perusahaan Pers yang melanggar ketentuan Pasal 5 ayat (1) dan ayat (2), serta Pasal 13 dipidana dengan denda paling banyak Rp. 500.000.000,00 (lima ratus juta rupiah).

(3) Perusahaan pers yang melanggar ketentuan Pasal 9 ayat (2) dan pasal 12 dipidana dengan pidana denda paling banyak Rp.100.000.000,00 (seratus juta rupiah).

Lebih jelasnya ketentuan dari Pasal 5 ayat (1) dan ayat (2), Pasal 9 ayat (2), Pasal 12 dan Pasal 13 UndangUndang No. 40 Tahun 1999, dapat dilihat penjelasan berikut di bawah ini:

Pasal 5 ayat (1) dan ayat (2):

(1) Pers nasional berkewajiban memberitakan peristiwa dan opini dengan menghormati norma-norma agama dan rasa kesusilaan masyarakat serta asas praduga tak bersalah.

(2) Pers wajib melayani Hak Jawab.

Pasal 9 ayat (2): Setiap Perusahaan pers harus berbentuk badan hukum Indonesia.

Pasal 12 : Setiap perusahaan pers wajib mengumumkan nama, alamat dan penanggungjawab secara terbuka melalui media yang bersangkutan khusus untuk penerbitan pers ditambah nama dan alamat percetakan.

Pasal 13 : Perusahaan pers dilarang memuat iklan:

a. yang berakibat merendahkan martabat suatu agama dan atau mengganggu kerukunan hidup antar umat beragama, serta bertentangan dengan rasa kesusilaan masyarakat.

b. Minuman keras, narkotika, psikotropika, dan zat adiktif lainnya sesuai dengan ketentuan peraturan perundang-undangan yang berlaku;

c. Peragaan wujud rokok dan penggunaan rokok.

Sanksi yang dapat dikenakan terhadap Pers yang merugikan nama baik seseorang menurut ketentuan pasal 18 Undang-Undang No. 401999 tentang Pers pada prinsipnya ada dua (2) bentuk sanksi yakni sanksi yakni Pidana penjara paling lama 2 tahun dan sanksi dan pidana denda paling banyak Rp.500.000.000,00 (lima ratus juta rupiah) dan paling rendah Rp.100.000.000,00 (seratus juta rupiah).

\section{Tindak Pidana yang Berhubungan Dengan Pertanggung Jawaban Pers.}

Mengenai tindak pidana yang berhubungan dengan Pers, sebelum lahirnya Undang-Undang No. 40 Tahun 1999 tetang Pers. Ketentuan mengenai tindak pidana pers ini diatur di dalam Kitab Undang-Undang Hukum Pidana (KUHP). Terutama di dalam Pasal 112, 113, 114, 115, 116 KUHP. $^{7}$

Untuk lebih jelasnya dapat di lihat pada penjelasan berikut di bawah ini:

\section{Pasal 112 menyatakan:}

Barang siapa dengan sengaja mengumumkan, atau mengambarkan atau menyampaikan surat, kabar dan keterangan tentang sesuatu hal kepada Negara asing, sedangkan diketahuinya, bahwa surat, kabar atau keterangan itu harus dirahasiakan karena kepentingan Negara, maka ia dihukum dengan hukuman penjara selama-lamanya tujuh tahun.

Ketentuan Pasal 112 KUHP tersebut di atas, dapatlah diketahui bahwa yang dilarang di sini ialah dua perbuatan yakni:

1. Mengumumkan surat kabar atau keterangan. Mengumumkan artinya menyiarkan kepada beberapa orang (orang banyak), jadi tidak cukup hanya diberitahukan kepada seorang saja.

2. Sedangkan Mengabarkan atau menyampaikan surat kabar atau keterangan kepada Negara Asing (pemerintah). Atau rakyat mengabarkan atau menyampaikan dengan langsung atau dengan perantaraan orang lain.

\section{Pasal 113 menyatakan :}

(1) Barang siapa dengan sengaja, untuk seluruhnya atau sebagian mengumumkan, atau memberitahukan maupun menyerahkan, kepada orang yang tidak berwenang mengetahui, surat-surat, peta-peta, rencana, gambar-gambar atau benda-bendayang bersifat rahasia dan bersangkutan dengan pertahanan atau keamanan Indonesia terhadap serangan dari luar, yang ada padanya atau yang isinya, bentuknya atau susunannya benda-benda itu diketahui olehnya, diancam dengan pidana penjara paling lama empat tahun.

${ }^{7}$ Roeslan Saleh, Perbuatan dan Pertanggungjawaban Pidana, Dua Pengertian Dasar, Jakarta: Liberty : 2009. hal. 81 
(2) Jika adanya surat-surat atau benda-benda pada yang bersalah, atau pengetahuannya tentang karena itu karena pencariannya, pidananya dapat ditambah sepertiga".

\section{Pasal 114 menyatakan:}

Barang siapa karena kealpaannya menyebabkan bahwa surat-surat itu atau benda-benda rahasia tersebut dalam pasal 113, yang tentang menyimpan atau menaruhnya menjadi tugasnya, diketahui oleh umum, mengenai bentuk dan susunannya, untuk seluruhnya atau sebagian, atau oleh orang yang tidak berwenang mengetahuinya, ataupun jatuh dalam tangannya, diancam dengan pidana penjara paling lama satu tahun atau denda paling banyak empat ribu lima ratus rupiah".

\section{Pasal 115 menyatakan :}

Barang siapa melihat atau membaca surat-surat atau benda-benda rahasia tersebut pasal 113, untuk seluruhnya atau sebagian, sedangkan diketahui atau selayaknya harus diduga bahwa benda-benda itu tidak dimaksud untuk diketahui olehnya; begitu pula jika membuat atau menyuruh buat salinan atau ikhtisar dengan huruf atau dalam bahasa apa pun juga; membuat atau menyuruh buat teraan, gambaran atau tiruan surat-surat atau benda-benda rahasia itu, atau jika tidak menyerahkan benda-benda itu kepada pejabat kehakiman, kepolisian atau pamongpraja, dalam hal bendabenda itu jatuh ke tanggannya, diancam dengan pidana penjara paling lama tiga tahun".

Yang dimaksud di dalam Pasal 115 KUHP tersebut di atas, pada intinya ialah:

1. Melihat atau mengetahui dan sebagainya surat-surat yang tersebut di dalam Pasal 115 KUHP.

2. Mendapatkan atau memperoleh surat-surat tersebut dan tidak menyerahkan surat-surat tersebut kepada pegawai - pegawai polisi atau yustisi.

\section{Pasal 116 menyatakan :}

Permufakatan jahat untuk melakukan kejahatan tersebut dalam pasal 113 dan 115, diancam dengan pidana penjara paling lama satu tahun".

Sedang rahasia jabatan/profesi yang berkaitan dengan media massa diatur dalam pasal 322 KUHP, yaitu:

(1) Barang siapa dengan sengaja membuka rahasia yang wajib disimpannya karena jabatan atau pencariannya, baik yang sekarang, maupun yang dahulu, diancam dengan pidana penjara paling lama sembilan bulan atau denda paling banyak sembilan ribu rupiah.

(2) Jika kejahatan dilakukan terhadap seorang tertentu, maka perbuatan itu hanya dapat dituntut atas pengaduan orang itu".

Menurut ketentuan Pasal 322 KUHP tersebut di atas yang dapat di hukum dengan pasal ini adalah:

1. Yang diberitahukan (dibuka) itu harus suatu rahasia.

2. bahwa orang tersebut diwajibkan untuk menyimpan rahasia tersebut dan ia harus betul-betul mengetahui bahwa ia wajib menyimpan rahasia itu.

3. bahwa kewajiban untuk menyimpan rahasia itu adalah akibat dari suatu jabatan atau pekerjaan yang sekarang, maupun yang dahulu pernah ia jabat; dan

4. membukannya rahasia itu dilakukan dengan sengaja.

Yang diartikan dengan "rahasia" yaitu barang sesuatu yang hanya diketahui oleh yang berkepentingan, sedangkan orang lain belum mengetahuinya.

Dalam praktek jurnalistik ketentuan itu dapat diberlakukan terhadap penyiaran berita yang oleh nara sumbernya sudah dinyatakan sebagai off the record, jika nara sumber itu keberatan terhadap penyiaran berita tersebut dan melakukan tuntutan hukum. Begitu pula kalau menyiarkan identitas nara sumber padahal yang bersangkutan sudah menyatakan minta dirahasiakan. Itu juga kalau nara sumber itu keberatan terhadap penyiaran berita tersebut dan melakukan tuntutan hukum.

Ketentuan lain Tindak Pidana Yang Berhubungan Dengan Pertanggung Jawaban Pers di dalam Kitab Undang-Undang Hukum Pidana dapat kita lihat di dalam Pasal 281, 282, Kitab Undang-Undang Hukum Pidana.

\section{Pasal 281 menyatakan :}

Diancam dengan pidana penjara paling lama dua tahun delapan bulan atau denda paling banyak tujuh ribu lima ratus rupiah:

$\mathrm{Ke}-1$. barang siapa dengan sengaja dan terbuka melanggar kesusilaan;

$\mathrm{Ke}-2$. baranng siapa dengan sengaja dan di muka orang lain yang ada di situ bertentangan kehendaknya, melanggar kesusilaan". 
Kesopanan di sini dalam arti kata "kesusilaan", perasaan malu yang berhubungan dengan nafsu kelamin misalnya bersetubuh, meraba buah dada orang perempuan, merapa tempat kemaluan wanita, memperlihatkan anggauta kemaluan wanita atau pria, mencium dan sebagainya.

\section{Pasal 282 menyatakan:}

(1) Barang siapa yang menyiarkan, mempertunjukkan atau menempelkan di muka umum tulisan, gambar atau benda, yang telah diketahui isinya dan yang melanggar kesusilaan; atau barang siapa dengan maksud untuk disiarkan, dipertunjukkan atau ditempelkan di muka umum, membikin tulisan, gambaran atau benda tersebut, memasukkan ke dalam negeri, meneruskannya, mengeluarkannya dari negeri, atau mempunyainya dalam persediaan; ataupun barang siapa secara terang-terangan atau dengan mengedarkan surat tanpa diminta, menawarkannya atau menunjukkannya sebagai bias di dapat, diancam dengan pidana penjara paling lama satu tahun enam bulan atau denda paling tinggi empat ribu lima ratus rupiah.

(2) Barang siapa menyiarkan, mempertunjukkan atau menempelkan di muka umum tulisan, gambaran atau benda yang melanggar kesusilaan, ataupun barang siapa, dengan maksud untuk disiarkan, atau dipertunjukkan atau ditempelkan di muka umum, membikinnya, memasukkannya ke dalam negeri, meneruskan, mengeluarkannya dari negeri atau mempunyai dalam persediaan, ataupun barang siapa secara terang-terangan atau dengan mengedarkan surat tanpa diminta, menawarkan atau menunjuknya sebagai bias didapat, diancam, jika ada alasan kuat baginya untuk menduga, bahwa tulisan, gambaran atau benda itu melanggar kesusilaan, dengan pidana penjara paling lama sembilan bulan atau denda paling banyak empat ribu lima ratus ribu rupiah.

(3) Kalau yang bersalah, melakukan kejahatan tersebut dalam ayat pertama, sebagai pencarian atau kebiasaan, dapat di jatuhkan pidana penjara paling lama dua tahun delapan bulan atau denda paling banyak lima ribu rupiah".

Perbuatan-perbuatn yang tercantum pada ayat (1) maupun ayat (2) dalam Pasal 282 KUHP ada tiga macam yakni:

1. Menyiarkan, menempelkan atau mempertontonkan dengan terang-terangan tulisan dan sebagainya.

2. Membuat, membawa masuk, mengirimkan langsung, mebawa keluar atau menyedia tulisan dan sebagainya untuk disiarkan, dipertontontan atau dipertempelkan dengan terang-terangan.

3. Dengan terang-terangan atau dengan menyiarkan suatu tulisan menawarkan dengan tidak diminta atau menunjukkan, bahwa tulisan dan sebagainya itu boleh didapat.

Bila dilihat perbedaan antara ayat (1) dan (2) Pasal 282 KUHP tersebut di atas, ialah ayat (1) orang yang harus mengetahui, bahwa isi tulisan dan sebagainya itu melanggar perasaan kesopanan, sedangkan ayat (2) nya orang itu tidak perlu mengetahuinya, sudah cukup apabila padanya ada alasan sungguh-sungguh untuk menduga, bahwa tulisan dan sebagainya itu melanggar perasaan kesopanan.

Tulisan, gambar atau barang itu harus melanggar perasaan kesopanan, perasaan kesusilaan, misalnya buku yang isinya cabul, gambar atau patung yang bersifat cabul, film yang isinya cabul dan sebagainya. Sifat cabul dan tidaknya itu harus ditentukan berdasarkan atas pendapat umum, tiap-tiap peristiwa harus ditinjau sendirisendiri, amat tergantung pada adapt istiadat dalam lingkungan itu.

Selain itu Tindak Pidana yang berhubungan dengan pertanggungjawaban Pers dapat pula dilihat di dalam Rancangan Kitab Undang-Undang Hukum Pidana antara lain dalam:

\section{Pasal 411 RUU KUHP menyantakan :}

Dipidananya dengan pidana penjara paling lama 1 (satu) tahun atau denda paling banyak kategori III setiap orang yang :

a. melanggar kesusilaan di muka umum, atau

b. melanggar kesusilaan di muka orang lain yang hadir tanpa kemauan sendiri.

\section{Pasal 412 menyatakan :}

(1) Dipidana dengan penjara paling lama 1 (satu) tahun atau denda paling banyak kategori III, setiap orang yang :

a. menyiarkan, mempertunjukkan atau menempelkan tulisan, gambar atau benda sehingga terlihat oleh umum, atau memperdengarkan rekaman sehingga terdengar oleh umum, yang isinya melanggar kesusilaan;

b. membuat atau mempunyai persediaan tulisan, gambar, atau benda dengan maksud untuk disiarkan, dipertunjukkan atau ditempelkan sehingga terlihat oleh umum atau menbuat atau mempunyai persediaan rekaman dengan maksud untuk diperdengarkan sehingga terdengar oleh umum,yang isinya melanggar kesusilaan; 
c. secara terang-terangan atau dengan kehendak sendiri mengedarkan, menawarkan, atau menunjukkan untuk dapat memperoleh tulisan, gambar, benda, atau rekaman yang isinya melanggar kesusilaan, atau

d. melakukan perbuatan sebagaimana dimaksud dalam butir a, b, atau c, jika ada alasan yang kuat baginya untuk menduga bahwa tulisan, gambar, benda atau rekaman tersebut melanggar kesusilaan.

(2) Jika pembuat tindak pidana sebagaimana dimaksud dalam ayat (1) melakukan perbuatan tersebut sebagai mata pencaharian atau kebiasaan dipidana dengan pidana penjara paling lama 2 (dua) tahun atau denda paling banyak kategori III".

\section{Pasal 413 menyatakan :}

Dipidana dengan pidana penjara paling banyak kategori I, setiap orang yang:

a. di muka umum menyanyikan lagu-lagu yang melanggar kesusilaan;

b. di muka umum mengucapkan pidato yang melanggar kesusilaan, atau

c. di tempat yang terlihat dari jalan umum membuat tulisan atau gambar yang melanggar kesusilaan".

\section{Pasal 414 menyatakan :}

Dipidana dengan penjara paling lama 1 (satu) tahun atau denda paling banyak kategori III, setiap orang yang :

a. menawarkan, memberikan untuk seterusnya atau sementara waktu, menyerahkan atau memperlihatkan tulisan, gambar, benda atau rekaman yang diketahui atau patut di duga melanggar kesusilaan, atau alat untuk mencegah atau menggugurkan kehamilan kepada orang yang diketahui atau patut di duga belum berumur 18 tahun (delapan belas) tahun atau belum kawin;

b. membacakan tulisan atau memperdengarkan rekaman atau memperlihatkan gambar yang diketahui atau patut diduga belum berumur 18 (delapan belas) tahun dan belum kawin; atau

c. melakukan perbuatan sebagaaimana dimaksud dalam butir a dan b, jika ada alasan kuat menduga, bahwa tulisan, gambar, benda atau rekaman tersebut menyinggung perasaan kesusilaan atau alat tersebut adalah alat untuk mencegah kehamilan".

\section{Pasal 415 menyatakan :}

Dipidana dengan pidana denda paling banyak kategori II, setiap orang yang :

a. di tempat lalu lintas umum secara terang-terangan mempertunjukkan atau menempelkan tulisan dengan judul, sampul, atau isi sehingga terbaca, atau mempertunjukkan atau menempelkan gambar atau benda, yang belum berumur 18 (delapan belas) tahun dan belum kawin;

b. di tempat lalu lintas umum, secara terang-terangan memperdengarkan isi tulisan yang mampu membangkitkan birahi orang yang belum berumur 18 (delapan belas) tahun atau belum kawin;

c. secara terang-terangan atau tanpa diminta menawarkan, mempertunjukkan tulisan, gambar, atau barang yang mampu membangkitkan birahi remaja atau secara terang-terangan atau dengan menyiarkan tulisan tanpa diminta, menunjukkan sebagai dapat diperoleh, tulisan atau gambar yang mapu membangkitkan birahi orang yang belum berumur 18 (delapan belas) tahun dan belum kawin;

d. menawarkan, memberikan untuk seterusnya atau sementara waktu, menyerahkan atau memperlihatkan gambar atau benda yang mampu membangkitkan birahi pada orang yang belum berumur 18 (delapan belas) tahun dan belum kawin".

\section{Kesimpulan}

Berdasarkan uraian yang telah penulis kemukakan di atas, dapatlah ditarik ke-dalam beberapa kesimpulan antara lain sebagai berikut:

1. Pertanggungjawaban Pers Terhadap Pemberitaan yang mencemarkan nama baik seseorang dapat dikenakan sanksi pidana selama 5 (lima) tahun penjara, selain itu pelakunya dapat pula dikenakan Denda paling banyak Rp. 500.000.000,00,- (lima ratus juta rupiah).

2. Tindak pidana yang berhubungan dengan Pers sebelumnya lahirnya Undang-Undang Nomor 40 Tahun 1999, telah diatur di dalam Kitab Undang-Undang Hukum Pidana seperti, pembocoran rahasia negara melalui surat kabar, Mempertunjukkan atau menempelkan dimuka umum yang isinya melanggar kesusilaan lal menyiarkannya untuk dipertontonkan sehingga membangkitkan nafsu birahi dan dan sebagainya.

\section{Daftar Pustaka}

Andi Zainal Abidin, Hukum Pidana, Jakarta: Sinar Grafika, 2003.

Harkristusi Harkrisnowo, Tindak Pidana Kessusilaan Dalam Perspektif Kitab Undang-Undang Hukum Pidana, Jakarta: Pustaka Firdaus, 2001. 
Ruslan Abdul Gani, Muhammad Mustajab. Analisis Normatif Tanggung Jawab Pidana Terhadap Pers Dalam Pemberitaan Yang Mencemarkan Nama Baik

Huda Chairul, Dari Tiada Pidana Tanpa Kesalahan Menuju Kepada Tiada Pertanggungjawaban Pidana Tanpa Kesalahan, Jakarta: Kencana Prenada Media, 2005.

Bambang Poernomo, Azas-azas hukum Pidana, Ghalia Indonesia, Yogyakarta, 2002.

Roeslan Saleh, Perbuatan dan Pertanggungjawaban Pidana, Dua Pengertian Dasar, Jakarta: Liberty : 2009.

Sudirman Teba, Hukum Media Massa Nasional, Pustaka Ir Van, Ciputat : 2006.

Soerjono Soekanto, Pengantar Penelitian Hukum, Universitas Indonesia, 2004.

Bambang Sunggono,.., Metodologi Penelitian Hukum, Raja Grafindo Jakarta, 2006.

Undang-Undang No. 40 Tahun 1999 tetang Pers

Undang-Undang Nomor 32 Tahun 2002 Tentang Penyiaran 